\title{
ECONOMIC DEVELOPMENT THROUGH INNOVATION: A COMPARISON BETWEEN FINEP AND THE DIALECTICS OF DEPENDENCY
}

\author{
${ }^{* 1}$ Nathan Peixoto Oliveira, ${ }^{2}$ Daniela Prado Damasceno Ferreira Reinecken \\ ${ }^{1,2}$ Université de Bordeaux, 33000, Bordeaux-AQ, France \\ *nathanpeixot@yahoo.com.br
}

\begin{abstract}
Given the progressive globalization, large companies and nations aim for high levels innovation and development. In Brazil, FINEP (Financier of Studies and Projects), is the responsible for providing subsidy, but there are still gaps in the technology employed and projects limitations, resulting in dependency. This work intends to correlate by a literature review, the FINEP financing model with Ruy Mauro Marini's Dependence Theory, since the innovation chain has a direct impact on the country's underdevelopment. Marini's theory emphasizes that we can observe economic dependence at the domestic level. However, by directing efforts to bring about technological innovation from the inside out, especially in the micro, small and medium enterprises, the State is contributing to the breakdown of the vicious cycle of surplus value obtained through the super exploitation of labor. As one of our results we came to conclude that it is necessary to analyze the efficiency of the financing by means of subsidy of the projects selected by the Program of Economic Subsidy for Technological Innovation, so that its impacts can be identified and its socioeconomic effects.
\end{abstract}

Keywords: Dialectics of Dependency; Economic Development; Innovation.

\section{DESENVOLVIMENTO ECONÔMICO ATRAVÉS DA INOVAÇÃO: UMA COMPARAÇÃO ENTRE A FINEP E A DIALÉTICA DA DEPENDÊNCIA}

\section{RESUMO}

Dada a progressiva globalização, grandes empresas e nações buscam altos níveis de inovação e desenvolvimento. No Brasil, a FINEP (Financiadora de Estudos e Projetos) é responsável por fornecer subsídios, mas ainda existem lacunas na tecnologia empregada e limitações de projetos, resultando em dependência. Este trabalho pretende correlacionar, através de uma revisão de literatura, o modelo de financiamento da FINEP com a Teoria da Dependência de Ruy Mauro Marini, uma vez que a cadeia de inovação tem um impacto direto no subdesenvolvimento do país. A teoria de Marini enfatiza que podemos observar a dependência econômica em nível doméstico. No entanto, ao direcionar esforços para promover a inovação tecnológica de dentro para fora, especialmente nas micro, pequenas e médias empresas, o Estado está contribuindo para o colapso do ciclo vicioso de obtido através da exploração excessiva do trabalho. O trabalho mostrou ser necessário analisar a eficiência do financiamento por meio do subsídio dos projetos selecionados pelo Programa de Subsídio Econômico à Inovação Tecnológica, para que seus impactos possam ser identificados e seus efeitos socioeconômicos. 
Palavras-chave: Dialética da Dependência; Desenvolvimento Econômico; Inovação.

\section{Como Citar:}

OLIVEIRA, Nathan Peixoto; REINECKEN, Daniela Prado Damasceno Ferreira. Economic Development Through Innovation: A comparison between FINEP and the Dialectics of Dependency. In: SIMPÓSIO DE PESQUISA OPERACIONAL E LOGÍSTICA DA MARINHA, 19., 2019, Rio de Janeiro, RJ. Anais [...]. Rio de Janeiro: Centro de Análises de Sistemas Navais, 2019.

\section{INTRODUCTION}

The present intensive economic dynamics of markets and the phenomenon of globalization produce ambiguous effects regarding economic development. Since they generate business opportunities, but at the same time, they increase competition between, both, companies and States. Given this scenario we can affirm that the permanent differentiation and competitive advantages are fundamental for the maintenance of the competitiveness of one nation against the others.

“(...) capitalist economy is not and cannot be stationary. Nor is it merely expanding in a steady manner. It is incessantly being revolutionized from within by new enterprise, i.e., by the intrusion of new commodities or new methods of production or new commercial opportunities into the industrial structure as it exists at any moment." (SCHUMPETER, 1950, p. 31-32).

The strategic incitement to economic development for Schumpeter is innovation, described as the commercial or manufacturing application of a new product, process or system of production, a new source of supply or market, a new form of business, financial organization or commercial. Given the progressive process of globalization, the intensification of competition among large companies is striking because they aim for extraordinary profits, which are the real impetus for the historical development of capitalism. Given this context, there is a tendency for technological diffusion, which ends up standardizing the goods to shorten the road to global exchange, and, consequently, the homogenization of the productive chain and its intensity.

Thus, Marini (1992) concludes that such trends provide a more solid basis for the recognition of the conditions of production and for the establishment of relative prices. By addressing, in the long term, national differences that affect the validity of the law of value.

In consonance with OECD - Organization for Economic Co-operation and Development, the incessant quest for differentiation is mandatory so that there can be a competitive advantage over competitors, thus enabling economies to foster long-term sustainable economic growth. Including investments in innovations that enable the creation or optimization of technologically superior processes and products.

The Dialectics of Dependency model proposed by Ruy Mauro Marini in 1973, is a counterpoint to the Theory of Dependency proposed by ECLAC, and focuses on technological and economic dependence of central and peripheral countries. Due to the export of technology by the central countries, which ensures their insertion in the globalized market, and by the export of goods of lower added value or raw material by the underdeveloped countries.

Although there are several agencies and programs created to foster technological innovation in Brazil, such as FINEP (Financier of Studies and Projects), the country is still far behind. Therefore, we have faced dependence on technological imports on several occasions, even though we have full internal production capacity. One of the greatest challenges that we 
face, however, is a higher risk for truthfully technology innovation and its distribution, that commonly is bared by the Brazilian government, not the private sector (Site 1).

Incentive Laws have also been created, such as tax incentives through the Computer Law (Law 10,664, dated 04/22/2003, and Law 11,077, Law no. 8,661 of June 2, 1993, and Chapter III of Law No. 11,196 of November 21, 2005) and the Law of Good Law No. 11,196 of November 21, 2005). In addition to programs offered by BNDES and FINEP. Especially the repayable financing programs of innovative projects by FINEP; financing to research projects that stimulate the approximation between the business sector and universities and research centers, made through sectoral funds.

At this conjuncture, we can observe a convergence of the financing policies of these projects with the Dialectic of Dependency of Ruy Mauro Marini. Since a large part of these contributions are allocated to technology import financing, an organic technological innovation is not being fostered, so a disruption of the dependency among Brazil and developed countries won't occur, since innovation is not only inexistent but also unsustainable in the long run (MARINI, 2000).

In addition to the factors highlighted above, it is worth noting that no analysis of any specific sector of the economy will be presented in this study. When contemplating the following explanation of Marcos Cintra, current president of FINEP, we can observe that the Institutions promoting technological innovation in Brazil are not properly integrated.

The present work aims to get a better understanding of the subvention of technology innovation conducted by FINEP. Given that the risk factor directly implies a greater or lesser degree of innovation, the present study questions whether the format of this financing program of innovative projects fosters a technological development with propensity to import. We also intend to correlate the current model of promotion to technological innovation by the subsidy, with Ruy Mauro Marini's Theory of Dependence, since the innovation chain has a direct impact on the country's underdevelopment.

The present study is relevant due to the degree of importance of technological innovation as a promoter for economic development, as well as the expressive public resources assigned to the economic subsidy for innovation by FNDCT. The subsidies conducted by FINEP during the period of 2006, the year of its first edition, to 2017 will be checked. The subsidy program's announcements were compared by content analysis, conforming aspects related to:

a) Objectives and official justifications, to understand the logic behind each Bidding and the underlying public policy;

b) The size of the company and the eligibility criteria of the companies, since although all the Edicts are focused on innovation, there are different parameters to be met;

c) Level of technological risk or innovation involved in the criterion of selection or merit, or as a guiding element for the choice of project. The study of this criterion is fundamental because, as will be demonstrated in the theoretical framework, the level of risk is inversely related to the level of investment of firms, and directly to that of the State;

d) Intensity of subsidies and adherence to the rules of the World Trade Organization: the intensity of subsidies, understood as the percentage of total subsidized projects, is an important parameter because it allows a direct comparison between the programs and, as part of the Agreement on Subsidies and Countervailing Measures, which has been ratified by all countries whose programs are part of the sample;

e) Tax incentive programs, other innovation support programs, or business plans of 
the companies participating in the grant program will not be part of the study and

f) The grant program is one of the pioneers in providing non-reimbursable public financial resources for innovation in private companies. Therefore, we will also evaluate the evolution of the Legislation guiding this agenda (Law of Good and Innovation Laws) in the Brazilian regulatory framework, which provides a new conjuncture of the Brazilian public administration and leaves many questions unanswered.

\section{MATERIALS AND METHODS}

Bresser-Pereira (2006) remember that, for several times, there were attempts of translating mathematically the development through economic models, most faulty due to the complexity of the process. It aims to study the economic systems, encompassing the study of society and the wealth distribution, within a framework of behavior and national institutions.

Even with simplified thinking, applied in relatively developed economies, it reflects the desire for greater productivity and competitiveness in the internal and external economic relations of the countries (CARDOSO JÚNIOR; SIQUEIRA, 2011). But development dependes not only on economic expansion, since it is a multidimensional phenomenon. Transformations in social and cultural structure are also import for progress.

The majority of the models were based in developed European countries, but may not be useful to explain peripheral and underdeveloped country. As Celso Furtado (1975) recalls in "Theory and Politics of Economic Development", the process of English industrialization do not suit many countries, as it took place internally and all knowledge and development came about organically in this country, like most developed countries.

Michael Todaro (1979) argues that the underdevelopment is the form of dependent capitalism, based on the international division of labor, which provides development for some restraint to those most dependent on large centers. For David S. Landes (2001), countries like Canada, Australia, Brazil and Argentina stand out among the countries of the West because of their good markets, governments and products with dealing with industrialized countries or, in the Brazilian case, having experienced late industrialization.

After the 1929, the Brazilian state began to focus on countercyclical policies and economic development, following the Keynes' theory (1936). For Alves and Lima (1991), a portion of public spending should be directed to financial and fiscal incentives to industrialization, that is, subsidized and long-term credit.

Development comes with a series of structural, environmental, social changes, technological progress, capital formation and concomitant integration with external markets (SOUZA, 2012). Following the same premises of the World Bank, there were more than fifty development banks in the world after the 1950s to foster regional development projects. As well as the Inter-American Development Bank (IDB), which operates in Latin American and Caribbean countries. It is noteworthy that these banks are active even in developed countries such as Japan (Japan Development Bank), Germany (Kreditanstalt für Wiederaufbau - KfW), among other member countries of the OECD (ROBERTS, 1999).

For there to be robust development, it is essential state planning, which essentially tends to target the short term and is subject to lack of liquidity and reliance on the international market. The Brazilian case confirms, not in its entirety, Nurkse's ${ }^{1}$ theory, because a complication for balanced growth in developing countries is the lack of resources

\footnotetext{
1 Ragnar Nurkse, a Danish economist based in the United States, summarized the ideas of Schumpeter, Young and Rosenstein-Roda, bringing clarity to Economic Development Theory and conceived a model to be followed by underdeveloped countries (Nurkse, 1951).
} 
for investment, both state and private, generating the need for the inflow of foreign investment in its most risky investments and loans (NERY, 2004).

It is not possible to think of economics as a market, but as a system, in which each nation works based on its precepts and related to the other countries of the world. The Brazilian domestic economy has always been very dependent on the world economy and, despite initiating development strategies, has always had concerns about structural issues, the international economy (oil crises) and economic stabilization, as occurred until nowadays.

\subsection{DEVELOPMENT AND DEPENDENCE IN LATIN AMERICA - DiALECTIC OF DEPENDENCE By MAURO MARINI}

In theory, the Latin American countries had no reason to industrialize, for they could earn part of their income in the face of an incontestable premise that Prebisch clearly explained in their research: The fruit of technical progress tends to be distributed equally to the whole community, either through falling prices or through the corresponding increase in income (PREBISCH, 1973).

However, after great efforts by the Latin American countries in the 1960s, industrialization met with a severe economic crisis and stagnation (MARINI 1992, p.80). Persisting the economic, technological and social problems, the Dialectics of Dependence arises, a critique of the ECLAC way of development. The development model (of the Dialectics of Dependency), proposed by Ruy Mauro Marini in 1973, focuses on technological and economic dependence, present in the capitalist model adopted in the relationship between central and peripheral countries. This relationship is marked by the export of technology by the central countries, which ensures their insertion in the globalized market, and by the export of products of lower added value or raw material by the underdeveloped countries.

Marini defends, through the Dialectics of Dependency, that the existence of peripheral countries is a necessity for the preexistence of countries considered as hegemonic of central capitalism. For him, the central countries have made capitalism and the Bourgeois Revolution a non-linear process, creating a context in which different socioeconomic formations have taken place, which constitute varied political regimes that generate relations of all kinds (MARINI, 1992, p.88).

In the $16^{\text {th }}$ century, Latin America is embedded in the international capitalism as a colony supplying precious metals and exotic goods, as well as importing goods from the European Continent. Such factors provide the necessary support for the development of commercial and banking capital, and of the manufacturing system of the colonizing countries, which would provide them the basis for the Industrial Revolution in the future.

Even though such development had given Latin American political independence, the Industrial Revolution of these countries made the flow of goods and capital into the Latin American countries, not England, but their needs. These peripheral countries exported primary goods to the central countries, to then acquire manufactured goods, leading to an overrun of imports on exports, and consequently to the growth of debts.

Among the characteristics of the Dialectics of Dependency are: the view that underdevelopment is closely connected with the expansion of the industrialized countries; the fundamental idea that development and underdevelopment are different aspects of the same universal process; fact that underdevelopment cannot be considered as the first condition for an evolutionary process; and, finally, the fact that dependence is not only an external phenomenon, but it also manifests itself in different forms in the internal structure (social, ideological and political). In general, it is shown that in the capitalist model development and underdevelopment are antagonistic because they are distinct models within the process of accumulation. It is concluded that dependence is a feature of peripheral economies, that is, as the logic of capitalist accumulation prevails, once a country or region becomes dependent, it 
will always be dependent.

From that moment on, the relationship between the Latin American countries and the European Continent becomes dependent and subordinate, and is characterized by the alteration or reformulation of the production model of the subordinate countries to meet the needs of the independent, generating, consequently, an even more deeply rooted dependence.

The accumulation of capital then takes on its own aspects. First, it is characterized by deep differences at the domestic level, in the local context of an inexpensive labor market, combined with capital-intensive technology. One of the means of exploiting wage labor that is most present in peripheral industrial countries, especially those submissive to the central powers, is the relative surplus value, which, fundamentally, results in the actual devaluation of labor power. The result, from the point of view of relative surplus value, is a violent exploitation of the labor force. Therefore, the immediate result of these mechanisms is a strong structural outflow of resources, which entails serious problems of external bottlenecks and external constraints to growth.

Once it increases its productivity, the worker starts to generate more production in less time, but as a value is not added with this increase of production, but reduced, mainly by the reduction of the social value of the unit of product, the capitalist seeks to increase production constantly (SADER; SANTOS, 2009, p. 175).

The scenario described above can be illustrated by the Economic Survey of Brazil of 2018 conducted by OECD. As reported by the referred Survey:

"Growth, underpinned by the growing workforce over many years, will slow down due to the rapid aging of the population. To maintain the growth potential of the economy, more investment is needed, which can raise productivity and, at the same time, the scope of future wage increases.” (Site 2)

Marini seeks to distinguish the main characteristics of the underdeveloped countries, differing from the view formulated by ECLAC, comprising the countries that are backward from a relation of world capitalism of dependence between the central countries (North America, Western Europe and Japan) and peripheral countries (Latin America, Africa and Asia), forged not only by the agrarian-export condition of the latter but by the international division of labor.

For Ruy Mauro Marini, in his writings from the 1980s to 1990s, the overexploitation of the labor force began to take on a new form in Latin America, reinforcing itself, starting in the 1970s, when the crisis of industrialization focused on the internal market, and a shift in the direction of its insertion into a globalized world economy under neoliberal policies. On the other hand, in the central countries also begins to develop mechanisms of super exploration of work previously restricted to the peripheral countries.

During the "inward-oriented" industrialization period from the 1940s to the 1980s, research and development (R \& D) and engineering efforts in Latin America never exceeded half a percentage point of GDP, which would be equivalent to one a mere fraction of what these ventures were in the economies of industrialized or more developed Southeast Asian countries. Approximately $80 \%$ of these efforts were executed and financed by public sector companies.

Parallel to this, but on a much smaller scale, the national innovation systems of the time also exhibited the participation of the engineering departments of local subsidiaries of transnational corporations and of many family owned SMEs (KATZ, 2005). In Brazil, usually the capital for innovation emerges from public sector, and according to FINEP:

"For smaller companies, the subsidy is relevant to leverage the investment potential and make feasible the proposed developments. For large companies, this importance is no longer so clear. The data suggest that this group has a 
very high investment potential in innovation, however, this capacity does not translate into a compatible innovative effort and, where this translates, the subsidy (...) constitutes a significant part of the funding.” (Site 3).

As stated by Katz (2005), these would be the culminating factors for why "inwardly oriented" industrialization was not enough to encourage these countries to pursue advanced technologies and to compel them to compete internationally.

Given the globalization, the intensification of competition among large companies is striking because they aim for extraordinary profits, which are the real impetus for the historical development of capitalism. Given this context, there is a tendency for technological diffusion, which ends up standardizing the goods to shorten the road to global exchange, and, consequently, the homogenization of the productive chain and its intensity.

Thus, Marini (1992) concludes that such trends provide a more solid basis for the recognition of the conditions of production and for the establishment of relative prices. By addressing, in the long term, national differences that affect the validity of the law of value.

\subsection{The Cycle of Capital in the Dependent Economy}

In the Latin American export economy, the formation based on the capitalist mode of production, the exploitation relation on which it is based, creates a cycle of capital that tends to reproduce on an extended scale the dependence in which it finds itself facing the international economy expansion (MARINI, 1992, p.134). When Latin America entered the stage of industrialization, it did so from the foundations created by the export economy, which, in the opinion of Marini, sacrifices individual consumption of workers in favor of exports to the world market, depresses levels of domestic demand, and erects the world market as the only outlet for production. To elucidate the issue addressed by Marini we can mention the export of crude oil and fuel imports from Brazil, whose level of development resembles countries like Nigeria and Angola (Site 4).

Brazil is one of the largest exporters of crude oil in the world, with the predominant oil on national soil being "heavy, dense and difficult to refine." Due to the technological lag in the process of refining crude oil the country is subject to the importation of refined petroleum so that it is mixed with the national heavy oil. Despite Petrobras' investments in refineries with the aim of optimizing and expanding its technical capacity to refine the product, in the first quarter of 2017 there was a 95\% drop in the level of refinery utilization to $77 \%$, resulting in an increase of $79.7 \%$ in the level of imports, reaching US \$ 4.357 billion.

In addition, the Agência Nacional do Petróleo, ANP (National Petroleum Agency) foresees serious supply problems if due attention is not paid to refining. As a result of these imports and technology lagged at the refineries, it increases the price of the fuel made available internally, resulting in the sacrifice of the Brazilian consumer (picture 1 and 2).

Picture 1: Foreign dependency: dependence (\% of liquid import/sales) 


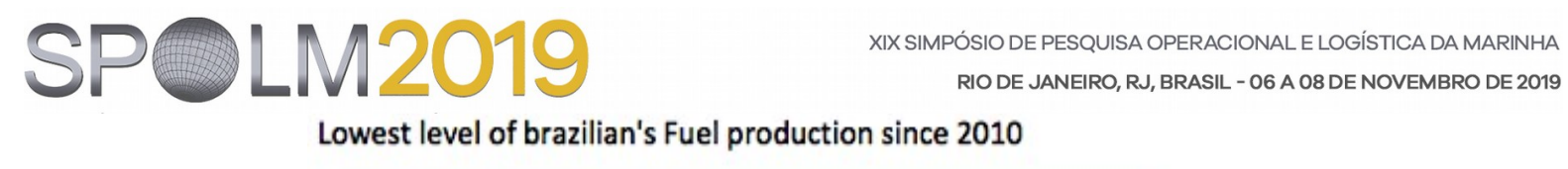

$\div$

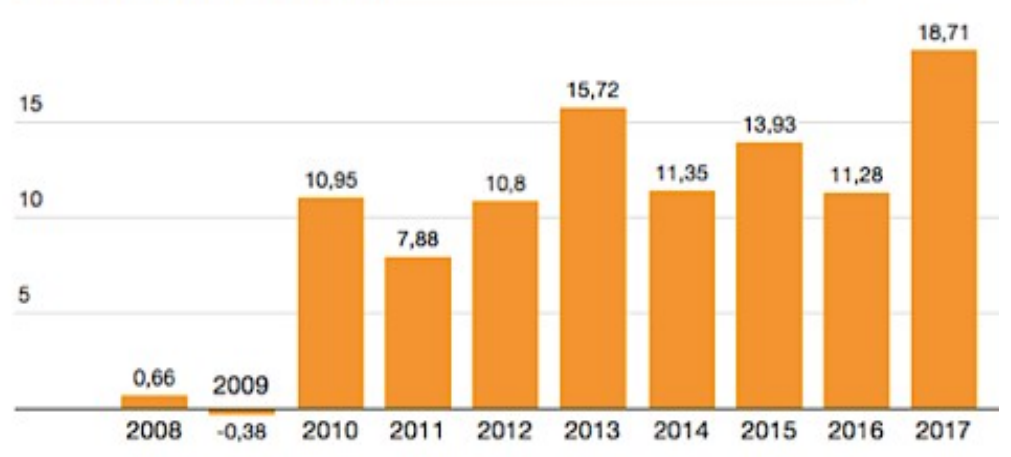

$\mathbf{7 7 \%}$ utilization of installed capacity at Petrobras refineries in the first quarter

Source: Site 5.

Picture 2: Foreign dependency: net imports Lowest level of brazilian's Fuel production since $\mathbf{2 0 1 0}$

NET IMPORTS, in millions of barrels (import - export) -

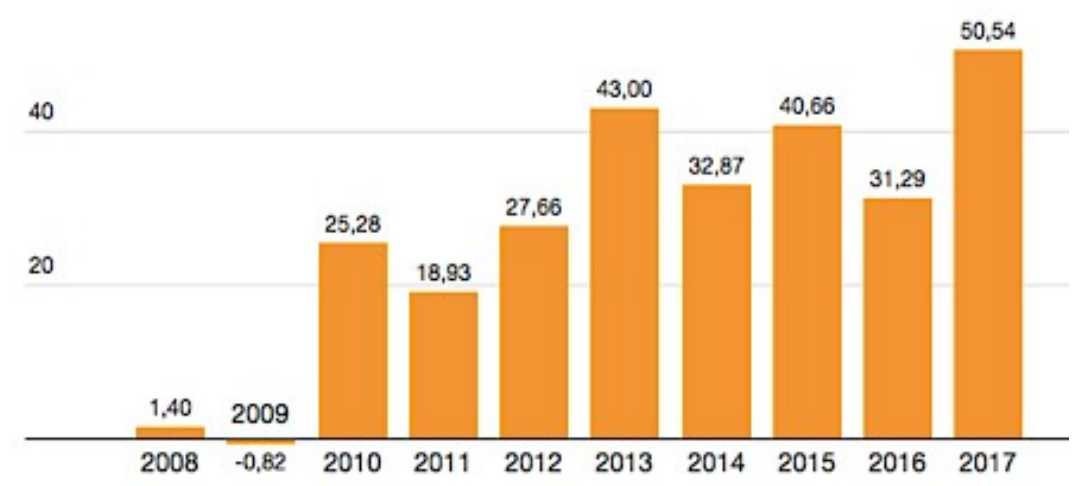

$\mathbf{7 7 \%}$ utilization of installed capacity at Petrobras refineries in the first quarter

Source: Site 5.

The permanent understanding that the export economy exerted on the individual consumption of the worker only allowed the creation of a weak industry, which only expanded when external factors (such as trade crises) partially closed access to import trade. Industrialization, in keeping with Marini (1992), does not create, as in classical economies, its own demand, but is born to meet an already constituted demand and will be structured aligned with the market demands coming from the advanced countries.

In the Dialectics of Dependency, it is stated that from the emergence of the need to generalize the consumption of manufactures, which occurs when the individual supply coincides broadly with the existing demand, there are two types of adaptations in the dependent industrial economy: the increase in the consumption of the middle classes and the effort to increase labor productivity to cheapen goods.

\subsection{ThechNology: Transfer, Economic DePENDENCE AND RISK}

Latin American industrialization corresponds to a new international labor division trasnfering to dependent countries lower stages of industrial production. Marini also notes the fact that in steel, which corresponded to a distinctive sign of the classical industrial economy, it was generalized to such an extent that countries like Brazil already export steel, keeping the 


\section{SPOLM2019}

XIX SIMPÓSIO DE PESQUISA OPERACIONAL E LOGISTICA DA MARINHA RIO DE JANEIRO, RJ, BRASIL - 06 A 08 DE NOVEMBRO DE 2019

most advanced stages in the manufacturing industry reserved for the imperialist centers.

Government authorities and local entrepreneurs seem to believe that countries can dispense with a firmer commitment to domestic knowledge generation and diffusion activities and that markets can adequately deal with issues of access to technology and know-how. Technology is an easily obtainable external input when needed, and therefore it is felt that local resources should not be used to finance an internal science and technology infrastructure. (KATZ, 2005).

Thus, as Katz points out, in addition to the United States, Western Europe and Japan today compete favorably in steel and automotive production, although they are not successful when it comes to the machine and tool industry, mainly the automated ones. There is a new hierarchy of the world capitalist economy, the basis of which is the redefinition of the international division of labor over the last fifty years.

Marini (1992) sees the need to emphasize that the export economy is the stage of transition to an authentic national capitalist economy, which is only formed when the industrial economy emerges; and that the general formula of capital also considers the transformation of simple commodity production into capitalist commodity production.

Rosenberg (2006) argues that technological transfers have existed since the beginning of history. However, after the Industrial Revolution, the process of technology transfer intensifies. Recipients of British technology were initially in a largely favorable position, as they could industrialize by simply transferring existing technology, rather than independent invention. This made it easier for the laggards in the industrialization race to enter the competitive world that began.

Such ease in entering the industrialized world, however, becomes a long-term disadvantage. The fact that a country finds itself inserted in a competitive capitalist society demands a constant turnover of products, which the industrial countries retain of advanced technology provide, besides generating innovations and technological updates. This entails, conforming to Rosenberg, a threat that the underdeveloped countries are in a vicious circle of dependency. "The twentieth century provides numerous examples of the replacement of new products with old products whose production in some less developed countries had been heavily dependent" (ROSENBERG, 2006: 366).

Schumpeter's theory demonstrates that differentiation, or technological innovation, is considered the propeller of capitalist development. In this case, industrial policy would assume the role of supporting this process of technical development, as opposed to traditional economic theory, which in turn focuses on the externalities and failures of the market (GUERRIERO, 2012, p.77). However, in the work of Cimoli et al. (2009, p.4) the authors observe that the last decades of industrialization have aggravated the discrepancy between per capita income levels, growth rate and technological divergences. Furthermore, the gap mentioned above is due to the difficulty in absorbing knowledge of production technologies developed by the countries that are at the technological frontier.

When there is no technology mastery by an economy, it will be vulnerable to demand changes and may only make some adjustments, mainly because that importing technology will never be easy. High levels of skill and technical competence in recipient countries are paramount. The most successful countries in the adoption of foreign technologies, since the technology export process began, were those with the most educated populations prevailed. The new technique implementation depends on the natural resources available in the country where the technology will be inserted, as well as the existence of administrative skills, organizational structures and the incentive system operation (ROSENBERG, 2006).

At the beginning of its development, the dependent economy is subordinated to the way capital accumulates in the industrial countries. Marini (1992, p. 157) says that industrial 
economies has repercussions in the world market to inflate the demand for raw materials, but the answer given by the export economy is strictly the reverse, because instead of doing it as a priority, it uses a greater extensive and intensive use of the workforce. Therefore, it lowers its organic composition and increases the value of the commodities produced, which raises the added value and the profit. Such growth generates, on the other hand, in the peripheral countries, a low profitability. To finally compensate for poor profit, there are practices of overexploitation of labor. Consequently, the dependent economy continues to expand its exports at ever more compensating prices to the industrial countries, and simultaneously maintains its attraction to foreign capital, thus postponing the process of dependence (Site 6).

\subsection{NATIONAL S\&T SySTEM, SUBVENTION TO INNOVATION AND FINEP}

As stated by the National Strategy for Science, Technology and Innovation (Encti) 2016-2022, published by the Ministry of Science, Technology, Innovations and Communications (MCTIC) on December 13, 2016, and validated by the National Science and Technology Council:

"The economic development of countries is increasingly based on innovation in scientific and technological development. It is no coincidence that several countries, such as the United States and China, have placed innovation at the heart of their growth recovery strategies after the 2008 crisis. This centrality of science, technology and innovation policies must be pursued by the Country, since it is fundamental to sustain the Brazilian economic development in the long term. Countries with successful late industrialization had their strategies based on decisive inputs in the context of education and science and technology" (Site 5).

The publication also states that the orientation of the effort of the Sistema Nacional de CT\&I (National S \& T System) must be aimed at supporting the promotion of Innovation, so that we can add value to domestic production and incorporate know-how in all segments of the economy. This being a "critical challenge to be faced".

It is only after 1951, with the creation of the Conselho Nacional de Desenvolvimento Científico e Tecnológico, $\mathrm{CNPq}$ (National Council for Scientific and Technological Development) and the Coordination for the Improvement of Higher Education Personnel (Capes), which is to be invested more concretely in scientific research in Brazil. However, with the creation of the National System of Science, Technology and Innovation (SNCT \& I), focused on ST \& I actions, we can observe the current level of development (Site 7).

The consolidation and construction of the national SNCT \& I took place in the 1960s, and despite the delay of three decades for its development, we can still find points to be developed because they are short of the first world countries. One of the points highlighted by Sérgio Machado Rezende, former Minister of Science and Technology (from July 2005 to December 2010) and former president of Finep, is "insufficient resources, bureaucracy and the fact that several FAPs do not work well, as the main weaknesses of the system " (Site 8)

With Decree-Law 0719, of July 31, 1969, the Fundo Nacional de Desenvolvimento Científico e Tecnológico - FNDCT (National Fund for Scientific and Technological Development) (FNDCT) is created within the scope of the Ministry of Planning. To finance priority projects for scientific and technological development, with the clear objective of providing support for the implementation of the Plano Básico de Desenvolvimento Científico e Tecnológico - PBDCT (Basic Plan for Scientific and Technological Development). As a result of this episode, on July 24, 1967, through DecreeLaw 61056 was created the Financier of Studies and Projects, FINEP, as Public Company linked to the Ministry of Planning (Site 9).

In 1998, the Fundo Setorial do Petróleo e Gás Natural (Sectorial Fund for Oil and 
Natural Gas), established by law, was created and, in 1999, the Fundos Setoriais de Ciência e Tecnologia (Sectoral Funds for Science and Technology) were created, both with the purpose of complementing the development and financing strategic sectors in Brazil. Soon they represent the majority of the resources allocated in the FNDCT. Currently, these funds are composed of 16 sectors of the economy, in which fourteen (specific) are for the areas of: ground transportation, aeronautics, agribusiness, Amazon, water transport and shipbuilding, biotechnology, energy, space, water resources, information technology , infrastructure, oil and natural gas, mineral and health; and two transversal ones composed by the Fundo para $o$ Desenvolvimento Tecnológico das Telecomunicações (Fund for the Technological Development of Telecommunications) and the Fundo Setorial do Audiovisual (Sectorial Audiovisual Fund). From the regulation of the FNDCT of 2006, there is the possibility of support from the funds to any area, these are called transversal actions.

\subsection{THE OSÉO INSTITUTION}

Created in 2005 by the merger of the Agence Nationale de Valorisation de la Recherche (Anvar), known as the French Agency for Innovation, with the Banque du Développement des Petites et Moyennes Entreprises (BDPME), OSEO has governed the French innovation system at one restructuring. By joining with a bank, ANVAR started to administer a more meaningful collection of support instruments, so that it could carry out its mission of "Supporting innovation and knowledge of small and medium-sized enterprises, sharing with them the risks of the phases of their life cycles." (Site 10)

OSEO Innovation is composed of programs aimed at financing development and innovation (creation of innovative companies, development of partnerships in national and international competitiveness poles, transfer of technology, among others). In these programs, the subsidy itself is not treated as a program, but it is one of the tools used, also associated with other support instruments, especially the zero-rate loan. In addition, this tool is used accordingly to the degree of maturity of the company and the technological and economic risk involved in the project.

As an example is worth mentioning the Innovation Stratégique Industrielle - ISI Program, created in 2008 subsidized portion reaches 50\% of the project, focusing on the promotion of strategic and cooperative projects, and should be composed of at least two companies. In addition, they must be projects that promote Schumpeter's "destructive creation", which promote technological leaps or significant ruptures, corroborating the proposal of Marini's Dependence Dialectics.

\section{THEME DISCUSSION AND RESULTS}

With the approval of Law 10,973, dated December 2, 2004, the regulatory framework for economic subsidization was established, and was regulated by Decree 5.563 in 2005, known as the Innovation Law. In addition to Law 11,196 of November 21, 2005, regulated by Decree No. 5,798 in June 2006, known as the Law of Good.

However, when carrying out an analysis of the Innovation Law of 2004, the economic subsidy is provided in Chapter IV, "From Incentive to Innovation in Companies". It is curious to note, however, that the first version of the Law does not deal with the subsidy, except from the second to fifth paragraph of article 19 of Law 13243, of 2016, known as the Legal Framework for Technology and Innovation, includes paragraph 8 of art. 19, which returns to address the subsidy when dealing with the resources allocated to it, delimiting its application in the "financing of research activities, technological development and innovation in companies, allowed its allocation to investments and chains, if predominantly in the activity financed". 
The third paragraph, which deals with the counterparty's demand for the beneficiary company, draws its attention to the first paragraph which, in turn, states that the "priorities of the national industrial and technological policy addressed in the main paragraph of this article will be established by regulation", or a completely disconnected topic.

In addition to a little clarification, Law 10,973 was regulated in 2005 by Decree 5.563, which, instead of deepening the instrument, only redirects the reference of the incorrect paragraph, attributing it to the second paragraph, which, in turn, only cites the instrument explaining that the same, and others (financing and shareholding), will require "project approval by the grantor body or entity." However, the treatment to be given to micro and small companies differs, which was not conjectured in the law.

In 2018, Decree 9,283 revokes Decree 5.563. One of the great repercussions observed concerns the Institutions that are part of the Public Administration, which promote research and development activities, and contract in accordance with Article 24, item XXI. The provision was included in Law 13,243, eliminating the obligation to bid when contracting goods, inputs, services and works, when linked to a research and development project approved by the administration, expanding the options available to public managers. While providing great benefits, this openness may facilitate the action of corrupt agents to divert public resources, which is a reality present in the country.

As of 2006, FINEP started to receive capital amounts from FNDCT, which in the 70s and 80s was its largest provider, to finance companies that applied for repayable loans. This was achieved by the introduction of Law 11,540, Law of the FNDCT, in 2007, which regulated in Chapter V - Application of Resources, Article 12, subsection II:

“...destined to projects of technological development of companies, in the form of a loan to Finep, that assumes the integral risk of the operation, observing, cumulatively, the following limits:

a) the annual amount of the operations may not exceed 25\% (twenty five percent) of the appropriations provided in the annual budget law to the FNDCT;

b) the balance of the credit operations carried out by Finep, including those contracted with FNDCT funds, may not exceed 9 (nine) times the shareholders' equity of said public company ".

As affirmed by FINEP, the funds transferred by the FNDCT, are made in the form of loans, returned through interest and amortization, and make up the Fund's second most important revenue source after the withdrawal of the oil royalties. Although the resources coming from FNDCT are of great relevance in the process of Financing Technological Development Projects of Companies (Site 11), a large part of the contributions made to FINEP are composed of multiple sources. We can see in the table below, prepared by the Corregedoria Geral da União, CGU (Federal Corregidor) with data provided by FINEP regarding the year 2016, the participation of the fundings in the liabilities of FINEP.

Table 1: Funding Liabilities Participation of FINEP 


\begin{tabular}{l} 
Funding \\
\cline { 1 - 3 }
\end{tabular}

Source: CGU Report (Site 12)

FINEP affirms (Site 13), that one of the main characteristics of the resources provided for credit operations by FNDCT is "the possibility of financing imported items, such as specialized technical equipment and services abroad, often indispensable in operations involving a high technological risk for companies." In addition, Rezende says that the main benefits of the creation of the FNDCT can be observed the design of the program of the National Institutes of S \& T and the economic subsidy for innovation.

Table 1 shows the presence of risk and innovation as criteria or guiding items for the selection of projects submitted to the FINEP grant approval process from 2006 to 2018. Once the 2015 Call for Proposals was excluded, of the technologies provided for in the Space Technology Transfer Agreement signed between the Agência Espacial Brasileira (Brazilian Space Agency), also known as AEB, and Thales Alenia Space (TAS), within the scope of Decree 7,769, dated 06/28/2012.

Table 2

\begin{tabular}{|c|c|c|c|c|}
\hline Year & Notice / Call & $\begin{array}{c}\text { Innovation in } \\
\text { Selection Criteria } \\
\text { or Merit }\end{array}$ & $\begin{array}{l}\text { Risk present in } \\
\text { the Selection } \\
\text { Criteria or Merit }\end{array}$ & $\begin{array}{l}\text { Risk / Innovation } \\
\text { as a beacon item }\end{array}$ \\
\hline 2006 & Chamada Pública MCT/Finep - PAPPE Subvençăo & No & No & No \\
\hline 2006 & $\begin{array}{c}\text { Chamada Pública MCT/Finep/Subvençăo } \\
\text { Econốmica à Inovaçăo }\end{array}$ & No & No & No \\
\hline 2007 & $\begin{array}{c}\text { Seleçăo Pública MCT/FINEP Subvenção } \\
\text { Econômica à Inovaçăo }\end{array}$ & Yes & No & Yes \\
\hline 2008 & $\begin{array}{l}\text { Seleçäo Pública MCT/FINEP/FNDCT- Subvenção } \\
\text { Econômica à Inovação }\end{array}$ & Yes & No & No \\
\hline 2009 & $\begin{array}{l}\text { Seleção Pública MCT/FINEP/FNDCT Subvenção } \\
\text { Econômica à Inovação }\end{array}$ & Yes & No & No \\
\hline 2010 & $\begin{array}{l}\text { Seleçăo Pública MCT/FINEP/FNDCT - Subvenção } \\
\text { Econốmica à Inovaçã̃o }\end{array}$ & Yes & No & No \\
\hline 2012 & $\begin{array}{l}\text { Seleção Pública MCTU/FINEP/FNDCT - Subvenção } \\
\text { Econômica à Inovação - Tema: Tecnologia } \\
\text { Edital de seleção pública conjunta FINEP/BNDES }\end{array}$ & Yes & Yes & Yes \\
\hline 2012 & $\begin{array}{l}\text { de apoio à inovaçăo tecnológica industrial no setor } \\
\text { de petróleo \& gás - Inova Petro }\end{array}$ & Yes & No & No \\
\hline 2013 & $\begin{array}{c}\text { Seleção Pública MCTUFINEP/FNDCT - Subvenção } \\
\text { Econômica à Inovação - TI MAIOR }\end{array}$ & Yes & Yes & Yes \\
\hline 2013 & $\begin{array}{l}\text { Seleção Pública MCTI/FINEP/FNDCT - Subvenção } \\
\text { Econômica à Inovação - Nanotecnologia } \\
\text { Seleçăo Pública MCTUFINEP/FNDCT - Subvençăo }\end{array}$ & yes & Yes & Yes \\
\hline 2013 & $\begin{array}{l}\text { Econômica à Inovação- Construção Sustentável o } \\
\text { Saneamento Ambiental } \\
\text { Seleção Pública MCTI/FINEP/FNDCT - Subvenção }\end{array}$ & Yes & Yes & No \\
\hline 2013 & $\begin{array}{l}\text { Econômica à Inovação - Produtos Obtidos por } \\
\text { Processos Biotecnológicos } \\
\text { CARTA CONVITE MCTIC/FINEP - Programa de } \\
\text { Apoio à Inovação Tecnológica - FINEP-TECNOVA }\end{array}$ & Yes & Yes & No \\
\hline 2018 & $\begin{array}{l}\text { \| 01/2018; MANUAL OPERACIONAL E DE } \\
\text { ORIENTACCÄO AO PARCEIRO } \\
\text { PROGRAMA FINEP TECNOVA \| }\end{array}$ & No & No & No \\
\hline TOTAL & $\begin{array}{l}\text { Yes\% } \\
\text { No\% } \\
\end{array}$ & $\begin{array}{l}77 \% \\
23 \% \\
\end{array}$ & $\begin{array}{l}38 \% \\
62 \% \\
\end{array}$ & $\begin{array}{l}31 \% \\
69 \% \\
\end{array}$ \\
\hline
\end{tabular}

Source: FINEP (Site 1)

The BNDES, in turn, establishes the following criteria for the use of the subsidy for technological innovation: 1. Degree of innovation and technological risk associated with Project; 2. Degree of importance / externalities of the technology and 3. Degree of nationalization of technology. The projects received scores of 1 to 3 for each of the criteria. 
An average over 2 could submit an economic grant proposal for analysis at FINEP (Site 1).

As shown above, the technological risk is present, but it is not the most relevant factor with BNDES, since the arithmetic mean between the three criteria is proposed.

In Table 2 it can be observed that in the period before the year of 2013 the criterion Technological Risk and Innovation were not present among the criteria or merits foreseen in the Edicts. Starting in 2013, despite the innovation criterion being in $77 \%$ of the analyzed Edicts, the Risk criterion appears in only $38 \%$ of the Edicts. Another relevant result was the low presence of both criteria as Balizer Item, being present in only $31 \%$ of the Edicts. What makes the weight of these criteria, throughout the Finep selection process, less determinant, going against the Dialectic of Dependency, as presented in chapter 3.1.

In Table 3, is shown the counterparty of the excess of edicts of Table 2:

\begin{tabular}{|c|c|c|c|c|c|c|}
\hline \multirow[b]{2}{*}{ Year } & \multirow[b]{2}{*}{ Notice / Call } & \multicolumn{5}{|c|}{ \% MINIMUM COUNTERVAILING } \\
\hline & & $\begin{array}{l}\text { MICRO } \\
\text { BUSINESS }\end{array}$ & $\begin{array}{l}\text { SMALL } \\
\text { BUSINESS }\end{array}$ & $\begin{array}{l}\text { MEDIUM } \\
\text { COMPANY }\end{array}$ & $\begin{array}{l}\text { MEDIUM- } \\
\text { GREAT } \\
\text { COMPANY }\end{array}$ & $\begin{array}{l}\text { BIG } \\
\text { COMPANY }\end{array}$ \\
\hline 2006 & $\begin{array}{c}\text { Chamada Pública MCT/Finep - PAPPE } \\
\text { Subvençäo }\end{array}$ & NA & NA & NA & NA & NA \\
\hline 2006 & $\begin{array}{l}\text { Chamada Pública MCT/Finep/Subvençăo } \\
\text { Econômica à Inovaçăo }\end{array}$ & $5 \%$ & $20 \%$ & $40 \%$ & NA & $60 \%$ \\
\hline 2007 & $\begin{array}{l}\text { Seleção Pública MCT/FINEP Subvenção } \\
\text { Econômica à Inovação }\end{array}$ & NA & NA & NA & NA & NA \\
\hline 2008 & $\begin{array}{l}\text { Seleção Pública MCT/FINEP/FNDCT- } \\
\text { Subvençăo Econômica à Inovação }\end{array}$ & $5 \%$ & $20 \%$ & $100 \%$ & NA & $200 \%$ \\
\hline 2009 & $\begin{array}{l}\text { Seleçâo Pública MCT/FINEP/FNDCT } \\
\text { Subvençăo Econômica à Inovação }\end{array}$ & $5 \%$ & $20 \%$ & $100 \%$ & NA & $200 \%$ \\
\hline 2010 & $\begin{array}{l}\text { Seleção Pública MCT/FINEP/FNDCT - } \\
\text { Subvenção Econômica à Inovação }\end{array}$ & $10 \%$ & $20 \%$ & $50 \%$ & $100 \%$ & $200 \%$ \\
\hline 2012 & $\begin{array}{c}\text { Seleção Pública MCTUFINEP/FNDCT - } \\
\text { Subvenção Econômica à Inovação - Tema: } \\
\text { Tecnologia Assistiva } \\
\text { Edital de seleçấo pública conjunta }\end{array}$ & $0 \%$ & $10 \%$ & $20 \%$ & $30 \%$ & $40 \%$ \\
\hline 2012 & $\begin{array}{c}\text { FINEP/BNDES de apoio à inovaçäo tecnológica } \\
\text { industrial no setor de petróleo \& gás - Inova } \\
\text { Petro }\end{array}$ & & & & & \\
\hline 2013 & $\begin{array}{l}\text { Seleção Pública MCTUFINEP/FNDCT - } \\
\text { Subvençăo Econômica à Inovação - TI MAIOR } \\
\text { Seleçăo Pública MCTUFINEP/FNDCT . }\end{array}$ & $0 \%$ & $10 \%$ & $20 \%$ & $30 \%$ & $40 \%$ \\
\hline 2013 & $\begin{array}{l}\text { Subvenção Econômica à Inovação - } \\
\text { Nanotecnologia } \\
\text { Seleção Pública MCTUFINEP/FNDCT - }\end{array}$ & $0 \%$ & $10 \%$ & $20 \%$ & $30 \%$ & $40 \%$ \\
\hline 2013 & $\begin{array}{l}\text { Subvenção Econômica à Inovação- } \\
\text { Construçăo Sustentável e Saneamento } \\
\text { Seleçằo Pública MCTIFINEP/FNDCT . }\end{array}$ & $0 \%$ & $10 \%$ & $20 \%$ & $30 \%$ & $40 \%$ \\
\hline 2013 & $\begin{array}{l}\text { Subvençắo Econômica à Inovação - Produtos } \\
\text { Obtidos por Processos Biotecnológicos } \\
\text { CARTA CONVITE MCTICIFINEP - Programa de } \\
\text { Apoio à Inovação Tecnológica - FINEP. }\end{array}$ & $0 \%$ & $10 \%$ & $20 \%$ & $30 \%$ & $40 \%$ \\
\hline 2018 & $\begin{array}{l}\text { TECNOVA ॥ 01/2018; MANUAL } \\
\text { OPERACIONAL E DE ORIENTAÇÄO AO } \\
\text { PARCEIRO }\end{array}$ & $10 \%$ & $10 \%$ & $15 \%$ & NA & $20 \%$ \\
\hline
\end{tabular}

Source: FINEP (Site 1)

The subsidy for technological innovation in enterprises is used extensively in developed countries, being the most favored by successful and emerging OECD members. As shown in Chapter 3.4 in Brazil, its main agent is FINEP. (http://fndct.mcti.gov.br/subvencaoeconomica-para-inovacao). This resource allows the sharing of costs and risks involved in $\mathrm{R}$ \& D between company and state through the application of non-reimbursable resources. Congruent with the rules set forth in article 8 of the WTO, it contemplates up to $75 \%$ for industrial research and $50 \%$ of initial capital for precompetitive development activities, a mandatory counterpart of the beneficiary company, following guidelines and conditions in the specific adjustment instruments. When evaluating Table 3, a more generous counterpart degree, smaller than the one indicated by the WTO, can be observed, being applied to micro, small and medium enterprises. Until the 2010 Call for Tender, the expected counterpart 
amounts for large companies were higher than those of the WTO. However, as of 2012, there has been a reduction in the counterpart amounts for large companies, and both the 2012 Call for Assistive Technology and all the 2013 Call for Proposals provide not a counterpart on the value of the Grant, but rather the value exceeded the expected minimum funding.

With the crisis of the real estate market of 2008, due to the economic conjuncture at the time, Brazil had a performance that stood out to the other economies momentarily. Considering this scenario, we can observe in Table 2 a high surcharge precisely in this period, especially in the case of medium-large and large-sized companies, reaching the level of $200 \%$ of counterpart for an amount exceeded.

The post-crisis economic situation was a crisis, and the policy of reducing the counterpart by an amount exceeded was coherent. Given the scenario of uncertainty in the domestic and foreign markets, the level of risk faced by companies becomes high when conducting a launch or insertion of new technology. In addition, PROTEC, Pró-Inovação na Indústria Brasileira (Pro-Innovation in Brazilian Industry) states that one of the biggest failures in the implementation of the technology subsidy in Brazil is due to the fact that:

"(...) in the company, the government grant can support the risk of rupture with the technological dependency of licensors, promoting innovation and contributing to the country's growth. In Brazil, the mechanism is still used inappropriately, (...) instead of being destined to the productive sector (...) is directed to specific products and sectors chosen by the Government “ (Site 14).

PROTEC's position on the practices adopted by FINEP, in guiding the subsidies that will be provided, when selecting specific sectors of the economy, to foster technological innovation is consistent with the Dialectics of Dependency, as it limits the scope of the program. In accordance with the Evaluation Report of the Economic Subsidy Program for the year 2010, none of the projects that participated in the program in 2009 involved a high degree of risk, and in 2011 and 2012 only 12.5\% and 15\%, respectively, were in this category.

The Evaluation Report of the 2012 Economic Subsidy Program ratifies the inconsistencies of the program, following the same premises of Cintra:

"Another issue that was much debated among FINEP consultants and technicians during the evaluation event was the relevance of support for large companies. During the presentations, he wondered what the company's behavior would have been if the grant project had not been approved. The result showed that support was essential for smaller companies, while larger companies would do so in all ways, even with changes in scale, scope and risk. This finding reinforces the need to discuss ways to prioritize resources for projects that would not effectively be developed without support (high technology and / or market risk)” (Site 15).

\section{FINAL CONSIDERATIONS}

Capitalism as we know it is maintained, mainly, due to the existence of the relation of dependence existing, mutually, between central and peripheral countries, we can conclude that the technological factor becomes determinant in the maintenance of such relation.

The constant technological upgrades and the growing development of the knowledge-retaining countries, in addition to technology-oriented research, mean that peripheral countries have their production turned to the foreign market, largely ignoring their own internal demand and to the needs of central countries. This leads them to import constantly, be it manufactured goods or even technology, constantly expanding their debts.

The retention of the technology does not guarantee the technological independence. Investing in research and development so that such technology does not become obsolete and 
can compete with core countries becomes crucial to its independence. Moreover, because there is a constant technological update, it is crucial that the importing country of technology has the capacity to apply it so that it is not at a greater competitive disadvantage.

In the previous chapters, the process of subsidizing technological innovation operated by FINEP in Brazil was analyzed. Despite being one of the tools most used by developed countries, the subsidy applied in isolation faces both legal obstacles and their nature. Therefore, we conclude that it could not substitute other credit operation instruments for the promotion of innovation, since they receive continuous flows. As the grant and other credit operations have different times, this can be considered as one of the barriers to System Integration approached by Cintra.

A possible solution to the poor integration between credit systems for financing innovation projects can be found in the model adopted by OSÉO. The French Agency, when using the grant program, determines that the success of the project is linked to its payment. In this way the risk of the project is shared more efficiently between company and public entity.

As some of the obstacles mentioned above we can enumerate the constant demand for public resources, and therefore, it is not a self-sustaining program; the grant can only afford the cost of the project, excluding expenses; the WTO determines through the level of technological risk maximum limits of $50 \%$ and $75 \%$ of State participation, which is not fully respected by the current policy used in the Foundation, however, the maximum amount of billing to be classified as small in the year of 2018 is 16 million reais, being below the international classifications, and therefore, there will probably be no contestations.

In the Evaluation Report of the Economic Subsidy Program for the year 2012, it has been shown that there was an evolution from $65 \%$ to $77 \%$ of the volume composed of micro, small and medium enterprises. Marini's theory emphasizes that we can observe economic dependence at the domestic level. However, by directing efforts to bring about technological innovation from the inside out, especially in the micro, small and medium enterprises, the State is contributing to the breakdown of the vicious cycle of surplus value obtained through the super exploitation of labor. It is therefore essential to continue this leverage.

By future works, tt is necessary to analyze the efficiency of the financing by means of subsidy of the projects selected by the Program of Economic Subsidy for Technological Innovation, so that its impacts can be identified and its socioeconomic effects verified.

\section{REFERENCES}

\subsection{Bibliographic REFERENCES}

[1] ALVES, E.L.G; LIMA, M.A. Crise e planejamento estratégico situacional. In: São Paulo em Perspectiva - Crise e Planejamento do Estado. São Paulo: SEADE, vol. 5, no 4, out/dez, 1991.

[2] BRESSER-PEREIRA, Luiz Carlos. O Conceito Histórico de Desenvolvimento Econômico. Rio de Janeiro: Fundação Getúlio Vargas, 2006.

[3] CARDOSO JÚNIOR, J.C.; SIQUEIRA, C. H. R. Complexidade e Desenvolvimento, Diálogos para o Desenvolvimento. Rio de Janeiro: IPEA, 2011.

[4] FURTADO, Celso. A Hegemonia dos Estados Unidos e o Subdesenvolvimento da América Latina; 1975.

[5] GUERRIERO, I. Formulação e avaliação de política industrial e o caso da PDP. 2012. 270 f. Tese (Doutorado em Economia da Indústria e da Tecnologia) - UFRJ, Rio de Janeiro, 2012.

[6] KEYNES, J. M. Teoria Geral do Emprego, do Juro e da Moeda. 1936. São Paulo: Editora Saraiva, 2012. 
[7] LANDES, David S. Why Are We So Rich and They So Poor?. Departamento de Economia de Harvard, p. 1-12, 2001.

[8] MARINI, Ruy Mauro. América Latina Dependência e Integração. São Paulo: Editora Brasil Urgente, 1992.

[9] MARINI, Ruy Mauro. Dialética da Dependência. Rio de Janeiro: Editora Vozes, 2000.

[10] NERY, Tiago. A Economia do Desenvolvimento na América Latina: Pensamento da ECLAC nos Anos 1950 e 1990. 2004, p. 20-51. Dissertação (Mestrado em Relações Internacionais) PUC-RJ, Rio de Janeiro, 2004. Disponível em: < http://www.maxwell.lambda.ele.puc-rio.br/5213/5213 3.PDF>. Acesso em: 25 mai. 2018.

[11] NURKSE, R. Problemas de Formação de Capitais em Países Subdesenvolvidos, RBE dezembro, Rio de Janeiro. 1951.

[12] PREBISCH, Raúl. Transformação e Dsenvolvimento: A Grande Tarefa da América Latina. 1973.

[13] SCHUMPETER, Joseph A., Capitalism, Socialism and Democracy. New York: Harper Perennial, 1950.

[14] SOUZA, N.J. Desenvolvimento Econômico. 6. ed. São Paulo: Atlas, 2012.

[15] TODARO, M. Introdução à Economia: Uma visão para o terceiro mundo. São Paulo: Campus, 1979.

\subsection{ELECTRONIC REFERENCES}

[16] Site 1 http://www.Finep.gov.br/images/imprensa/0904cintranoseua.pdf access in june, 2018.

[17] Site 2 http://www.oecd.org/eco/surveys/Brazil-2018-OECD-economic-survey-overviewPortuguese.pdf access in august, 2018.

[18] Site 3 http://download.finep.gov.br/programas/subvencao/RelatoriodeAvaliacao3CicloSubvencao-2011-FinalInternet-DAGI.pdf access in august, 2018.

[19] Site 4 https://fgvenergia.fgv.br/noticias/brasil-troca-petroleo-cru-por-refinado access in august, 2018.

[20] Site 5 http://www.Finep.gov.br/images/a-Finep/Politica/16 032018 Estrategia Nacional de Ciencia Tecnologia e Inovacao 2016 2022.pdf access in august, 2018.

[21] Site 6 http://www.dicyt.com/viewNews.php?newsId=22046 access in august, 2018.

[22] Site 7 https://atlas.media.mit.edu/en/profile/country/bra/\#Trade Balance, access in june, 2018.

[23] Site 8 http://www.dicyt.com/viewNews.php?newsId=22046), access in june, 2018.

[24] Site 9 http://www.Finep.gov.br/a-Finep-externo/fontes-de-recurso/fndct-fundo-nacional-dedesenvolvimento-cientifico-e-tecnologico/100-financiamento-de-projetos-de-desenvolvimentotecnologico-de-empresas, access in june, 2018.

[25] Site 10 http://www.oseo.fr/notre mission/qui sommes nous/organisation, access in august 2018.

[26] Site 11 http://www.Finep.gov.br/a-Finep-externo/fontes-de-recurso/fndct-fundo-nacional-dedesenvolvimento-cientifico-e-tecnologico/100-financiamento-de-projetos-de-desenvolvimentotecnologico-de-empresas access in june, 2018.

[27] Site 12 https://auditoria.cgu.gov.br/download/10881.pdf access in june, 2018. 
[28] Site 13 http://www.Finep.gov.br/a-Finep-externo/fontes-de-recurso/fndct-fundo-nacional-dedesenvolvimento-cientifico-e-tecnologico/100-financiamento-de-projetos-de-desenvolvimentotecnologico-de-empresas access in july, 2018.

[29] Site 14 http://www.protec.org.br/secoes/page/20/Subvencao-Economica access in july, 2018.

[30] Site 15 http://download.Finep.gov.br/programas/subvencao/RelatoriodeAvaliacao3CicloSubvencao-2011-FinalInternet-DAGI.pdf access in july, 2018. 